\title{
Six Cases of Nasal Cavity and Nasopharyngeal Tuberculosis
}

\author{
Chang Joon Lee ${ }^{1}$, Young Ho Choi ${ }^{1}$, Eun Sun Jeon ${ }^{1}$ and Dong Hoon Lee ${ }^{2}$ \\ ${ }^{1}$ Department of Otolaryngology-Head and Neck Surgery, Chonnam National University Hospital, Gwangju; and \\ ${ }^{2}$ Department of Otolaryngology-Head and Neck Surgery, Chonnam National University Medical School Hwasun Hospital, \\ Hwasun, Korea
}

\section{비강 및 비인두결핵 6예}

이창준 ${ }^{1} \cdot$ 최영호 $^{1} \cdot$ 전은선 $^{1} \cdot$ 이동훈 $^{2}$

전남대학교 의과대학 전남대학교병원 이비인후-두경부외과학교실, ${ }^{1}$

전남대학교 의과대학 화순전남대학교병원 이비인후-두경부외과학교실 ${ }^{2}$

\author{
Received June 11, 2013 \\ Revised September 29, 2013 \\ Accepted September 30, 2013 \\ Address for correspondence \\ Dong Hoon Lee, MD \\ Department of Otolaryngology- \\ Head and Neck Surgery, \\ Chonnam National University \\ Medical School Hwasun Hospital, \\ 322 Seoyang-ro, Hwasun-eup, \\ Hwasun 519-763, Korea \\ Tel +82-61-379-7760 \\ Fax +82-61-379-7761 \\ E-mail leen31@hanmail.net
}

Tuberculosis of the nasal cavity and nasopharynx is extremely rare. The diagnosis is frequently delayed because of unfamiliarity with the disease. It is difficult to make an accurate diagnosis of tuberculosis of the nasal cavity and nasopharynx on imaging findings alone; a biopsy is required to confirm the diagnosis and to differentiate it from malignancy and the other conditions. The authors have experienced 6 cases of tuberculosis of the nasal cavity and nasopharyx. We report them with review of literatures. Korean J Otorhinolaryngol-Head Neck Surg 2013;56:795-9

Key Words Nasal cavity · Nasopharynx · Tuberculosis.

\section{서 론}

세계보건기구의 발표에 따르면 2011년 한 해 동안 세계적으 로 모두 870만 명의 새로운 결핵 환자가 발생하였으며 140만 명이 결핵으로 사망했다. 폐외 기관을 침범하는 폐외결핵은 전 체 결핵의 약 9.7 46\%를 차지하는데, 특히 비강 및 비인두결 핵은 매우 드물며 초기 증상이 비특이적으로 조기 진단이 어 렵다. 따라서, 치료에 반응을 잘 하지 않는 비루, 비폐색이 있 는 환자에서 비점막의 궤양이나 육아 병변이 있을 때는 결핵 의 가능성을 염두에 두어야 한다. 저자들은 2005년부터 비강 및 비인두에 발생한 결핵 6예(Table 1)를 경험하였기에 문헌고 찰과 함께 보고하는 바이다.

\section{증 례}

\section{증 례 1}

29세 여자 환자가 2개월 전부터 시작된 좌측 코막힘 및 농 성 비루를 주소로 내원하였다. 비인두경 검사 상 좌측 비중격 의 전반적인 비후와 쉽게 출혈하는 궤양성 병변이 관찰되었다 (Fig. 1A). 외래에서 시행한 두 차례의 조직 검사 상 괴사를 동 반한 만성 육아종성 염증 소견을 보였으나, 결핵에 대한 중합 효소 연쇄반응(Tuberculosis-Polymerase Chain Reaction, $\mathrm{Tb}-\mathrm{PCR}$ )에서는 두 차례 모두 음성 소견을 보였다. 결핵피부 반응검사(Purified Protein Derivatives, PPD)와 인터페론감 마분비검사법(Quantiferon-Tb) 모두 양성 소견을 보여 비강결 핵으로 진단하였고, isoniazid $300 \mathrm{mg}$, rifampin $600 \mathrm{mg}$, ethambutol $1200 \mathrm{mg}$, pyrazinamide $1500 \mathrm{mg}$ 을 9개월간 투여 하였다. 환자는 약물 투여 후에 완치되어 재발 소견 없이 외래 
통원 치료 중이다(Fig. 1B).

\section{증 례 2}

30 세 남자 환자가 1 주일 전부터 발생한 인두부 통증 및 경 부 종물, 고개를 돌릴 때 악화되는 경부 통증을 주소로 내원 하였다. 신체검사 상 우측 경부 부종 소견을 보였으며 비인두 측 벽에 약 $2.0 \mathrm{~cm}$ 크기의 선홍색 빛을 띠는 육아종성 병변이 발 견되었다(Fig. 2A). 이곳에서 시행한 조직 검사 상 괴사를 동 반한 만성 육아종성 염증 소견 보였으나, $\mathrm{Tb}-\mathrm{PCR}$ 에서는 음
성 소견을 보였다. 경부 전산화단층촬영상 우측 비인두에 약 $2.0 \times 1.4 \mathrm{~cm}$ 의 비균일하게 조영되는 종괴가 보였으며, 후인두 공간 내부에도 $2.0 \times 2.0 \mathrm{~cm}$ 의 중심부가 괴사되어 있는 주위 조 영증강되는 부위가 있었다. 가슴 흥부 전산화단층촬영에서도 양측 폐 첨부에 결핵을 의심할 만한 병변이 관찰되어, 비인두 와 임파선의 폐외결핵 및 폐결핵으로 진단하고 항결핵 약물 을 투여하였다. 약물 복용 2개월 후 우측 후인두 공간의 농양 이 증가하는 소견을 보여 전신마취하 절개 및 배농술을 시행하 였다(Fig. 2B). Isoniazid $400 \mathrm{mg}$, rifampin $600 \mathrm{mg}$, etham-

Table 1. Characteristics of the tuberculosis of nasal cavity and nasopharynx

\begin{tabular}{|c|c|c|c|c|c|c|c|c|c|}
\hline Case & Age/sex & $\begin{array}{l}\text { Pul. } \\
\text { Tb }\end{array}$ & Sites & $\begin{array}{c}\text { AFB } \\
\text { stain (S) }\end{array}$ & Culture (S) & QFT & $\begin{array}{l}\text { Tb- } \\
\text { PCR }\end{array}$ & Treatment & $\begin{array}{c}\text { Duration } \\
\text { of treatmen }\end{array}$ \\
\hline 1 & $29 / F$ & - & Septum & N.C. & N.C. & + & - & HERZ & 9 month \\
\hline 2 & $30 / \mathrm{M}$ & + & Nasopharynx & - & - & N.C. & - & HERZ & 14 month \\
\hline 3 & $22 / F$ & - & Inferior turbinate & N.C. & N.C. & N.C. & - & HER & 9 month \\
\hline 4 & $24 / F$ & - & $\begin{array}{l}\text { Septum } \\
\text { Inferior turbinate }\end{array}$ & N.C. & N.C. & N.C. & + & HERZ & 9 month \\
\hline 5 & $51 / F$ & - & Nasopharynx & N.C. & - & + & - & HER & 9 month \\
\hline 6 & $30 / F$ & - & Inferior turbinate & - & - & N.C. & - & HERZ & 12 month \\
\hline
\end{tabular}

Pul.: pulmonary, Tb: tuberculosis, AFB: Acid Fast Bacilli, S: sputum, QFT: Quantiferon-Tb test, PCR: polymerase chain reaction, F: female, M: male, N.C.: not checked, HERZ: Isoniazid, ethambutol rifampin, pyrazinamide, HER: Isoniazid, ethambutol, rifampin

Fig. 1. Nasal endoscopic findings of case 1 . There is the friable and granulomatous mass (arrow) on the left side of septum (A). The septal lesion was improved after the completion of 9-month course of anti-tuberculosis agents $(\mathrm{B})$.
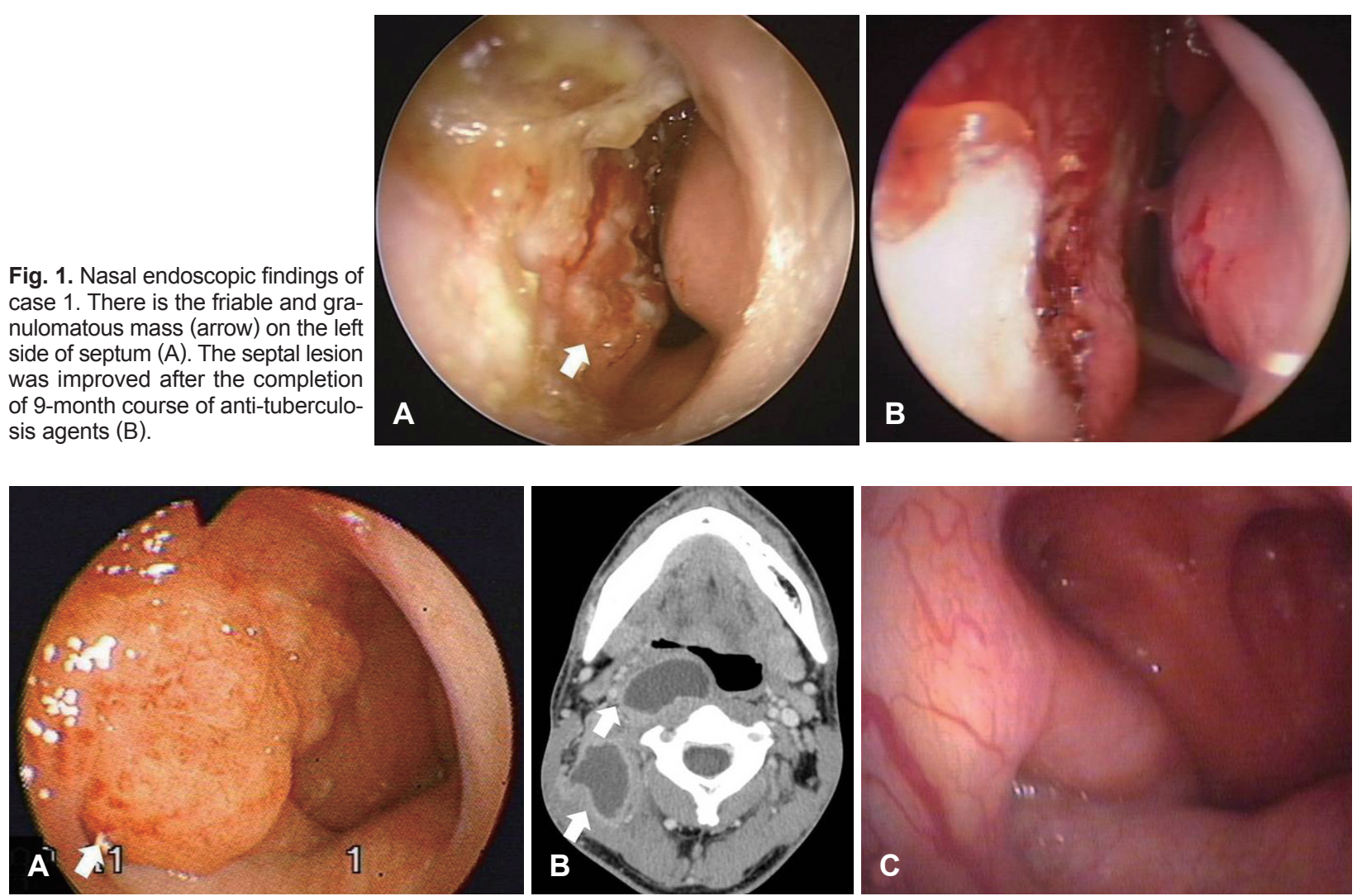

Fig. 2. Nasal endoscopic findings and radiologic examination of case 2. It shows multiple granular mass (arrow) on the right lateral wall of the nasopharynx (A). Axial contrast-enhanced computed tomography scan demonstrates centrally necrotic lesions (arrows) with enhanced wall in right retropharynx and posterior neck (B). There is no recurrence lesion of the nasopharynx at 5 year after anti-tuberculosis treatment $(\mathrm{C})$. 
Fig. 3. Nasal endoscopic findings of case 5 . It shows easily bleeding exophytic mass (arrow) on the nasopharynx (A). After the completion of 11month course of anti-tuberculosis agents, nasopharyngeal mass was disappeared (B).
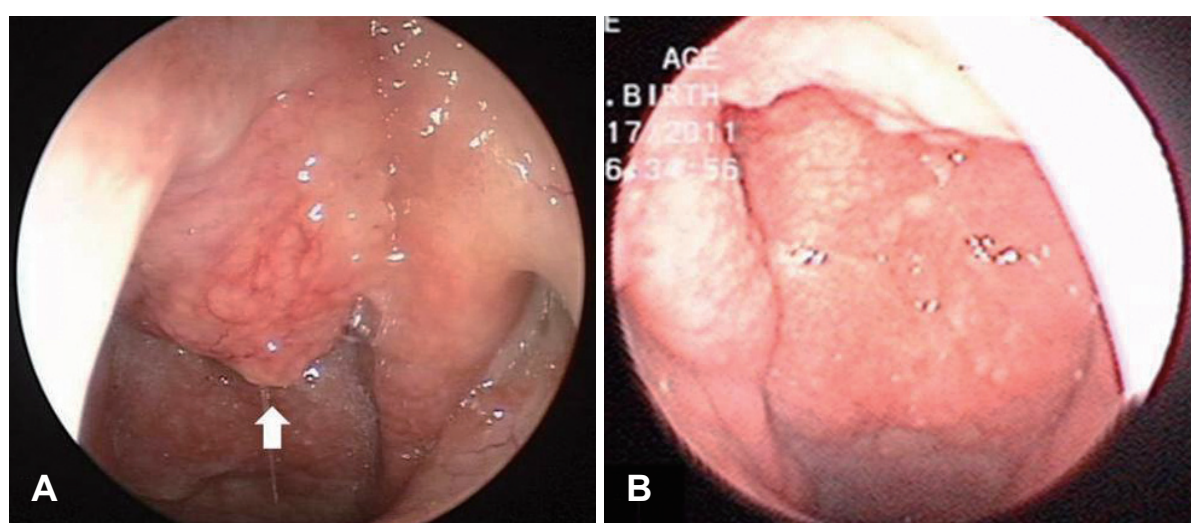

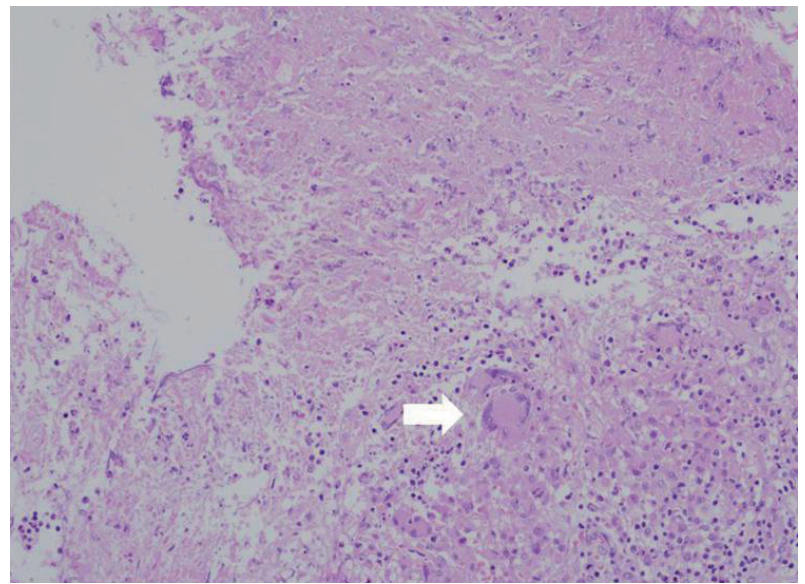

Fig. 4. Histopathologic finding of case 6 demonstrates typical granuloma (arrow) with central necrosis, epitheloid cells and lymphocytes $(H \& E, \times 200)$.

butol $800 \mathrm{mg}$, pyrazinamide $1500 \mathrm{mg}$ 을 첫 4개월간 투여하 였으나, 이후 관절통이 있어 pyrazinamide는 중단하였으며, 나 머지 약물은 10 개월간 더 투여하였다. 현재 환자는 5년째 재 발 소견 없이 외래 통원 치료 중이다(Fig. 2C).

\section{증 례 3}

22세 여자 환자가 1년 전부터 시작된 우측 코막힘으로 개인 병원에 내원하여, 하비갑개의 종물을 발견 후 내시경을 이용 한 제거술을 시행받았다. 그러나, 수술 이후에도 지속적으로 점막의 가피, 육아 조직 및 괴사 조직이 관찰되어 재시행한 조 직 검사 상 베게너 육아종이 의심된다하여 본원으로 전원되 었다. 확진을 위하여 본원에서 다시 조직 검사 및 혈액 검사를 시행하였다. 면역 혈청 검사에서는 anti-neutrophilic cytoplasmic antibibody가 음성이었으며, 다시 시행한 조직 검사에 서 건락성 괴사를 동반한 만성 육아종성 염증 소견을 보여 비 강결핵에 합당한 소견을 보였다. 흥부 방사선 소견은 정상이었 고, 부비동 전산화단층촬영상 우측 상악동이 혼탁한 소견 이 외에 특이 소견은 보이지 않았다. 비강결핵 진단 하에 isonia- zid 300 mg, rifampin 600 mg, ethambutol $1200 \mathrm{mg}$ 을 9개 월간 투여 후 회복하였고, 재발 없이 외래 통원 치료 중이다.

\section{증 례 4}

24세 여자 환자가 1 개월 전부터 발생한 우측 코막힘을 주소 로 개인병원에 들렀다가 우측 비중격 후방의 병변이 발견되어 본원으로 전원되었다. 개인병원 치료시 스테로이드를 복용하 면 병변 크기가 감소하고 중단하면 다시 커지는 양상이 반복되 었다고 했다. 비인두경 검사 상 우측 비중격 후방 및 하비갑개 에 육아종성 병변이 보였고, 조직 검사 상 건락성 괴사를 동반 한 만성 육아종성 염증 소견을 보였으며 Tb-PCR 상 양성 소 견을 보였다. 비강결핵 진단 하에 isoniazid $300 \mathrm{mg}$, rifampin $600 \mathrm{mg}$, ethambutol $800 \mathrm{mg}$, pyrazinamide $1500 \mathrm{mg}$ 을 6개 월간 투여하였다. 치료 종료 후 1 년이 지난 현재 재발 없이 추 적 관찰 중이다.

\section{증 례 5}

51세 여자 환자로 종합검진으로 시행한 양전자 단층촬영전산화단층촬영술(positron emission tomography computed tomography, PET-CT) 상 우연히 비인두와 양측 경부 임 파선의 항진된 대사 소견이 관찰되어 본과에 의뢰되었다. 비 인두경 검사 상 비인두에 쉽게 출혈하는 외장성 종물 소견을 보였다(Fig. 3A). 외래에서 시행한 비인두의 조직 검사 상 중 심 괴사를 동반한 만성 육아종성 염증으로 결핵에 합당한 소 견을 보였고, 경부 임파선에서 시행한 세침흡입검사에서는 급 성 임파선염으로 진단되었다. $\mathrm{Tb}-\mathrm{PCR}$ 상 음성 소견을 보였지 만, $\mathrm{PPD}$ 와 Quantiferon-Tb 검사 상 양성 소견을 보였다. 비강 결핵 진단 하에 항결핵제인 isoniazid $300 \mathrm{mg}$, rifampin 600 $\mathrm{mg}$, ethambutol $1200 \mathrm{mg}$ 을 9개월간 투여 후 경과 관찰 중 비인두의 종괴는 사라졌고 점막의 비후만 남아있었으며(Fig $3 \mathrm{~B})$, 시행한 부비동단층촬영 상 비인두 및 경부 임파선 병변 의 소실을 관찰할 수 있었다. 


\section{증 례 6}

30세 여자 환자가 2년여 전부터 지속된 우측 눈물 흘림증 및 후비루를 주소로 내원하였다. 비인두경 검사 상 우측 하비갑 개 및 하비도에 경계가 불분명한 종괴가 있어, 시행한 조직 검 사 상 괴사 조직을 동반한 육아종성 염증 소견을 보여 비강결 핵을 의심하였으며(Fig. 4), Tb-PCR과 PPD에 모두 음성 소 견을 보였다. 흥부 방사선 검사 상 정상 소견을 보였다. Isoniazid $400 \mathrm{mg}$, rifampin $450 \mathrm{mg}$ 을 1년간, ethambutol $800 \mathrm{mg}$, pyrazinamide $500 \mathrm{mg}$ 을 3개월간 투여 후 회복되었다.

\section{고 찰}

비강결핵은 연구개, 비인두, 비강 내의 궤양성 병변을 가진 젊은 남자의 부검을 통해 1761년 Giovanni Morgani에 의해 처음으로 기술되었다. ${ }^{2)}$

결핵은 신체 모든 장기에서 생길 수 있으며 두경부 영역에 서는 후두, 중이, 편도, 연구개, 비강, 침샘 등에서의 발생이 보 고되었다. ${ }^{3)}$ 특히 비강결핵은 폐결핵 후 이차적으로 발생하는 속발성 비결핵과, 폐결핵 없이 발생하는 원발성 비결핵으로 분 류된다. ${ }^{4)}$ 속발성 비결핵의 경우가 원발성 비결핵에 비해 많은 것으로 알려져 있는데 비강 내의 섬모운동, 비강 분비물의 살 균성과 비모의 여과작용 때문으로 생각되고 있다. ${ }^{5)}$ 그러나 원 발성 비결핵이 더 많다는 보고도 있으며,7) 본 연구에서도 총 6예 중 5예에서 원발성 비강 및 비인두결핵으로 진단되었다.

임상적으로 비강결핵은 아주 드물고 초기에는 비특이적인 증상을 나타내어, 조기 진단과 치료가 어렵다. 증상으로는 비 폐색이 가장 흔하고, 종괴, 비루, 비출혈 등이 있을 수 있다. ${ }^{4)}$ 본 연구에서도 비강 내에 병변이 존재하는 경우는 비폐색, 비 루 등의 코 증상을 주로 호소하였다. 그러나, 비인두에 발생한 결핵의 경우에는 임파선결핵으로 인하여 진단되었거나, 방사 선 촬영 상 우연히 발견되는 등 비강결핵보다 더욱 비특이적 인 증상을 나타내었다.

진단이 조기에 되어 항결핵제 치료를 바로 시행된 경우 합병 증 없이 치료가 가능하나 치료가 늦어지는 경우 비루관의 폐 쇄, 복시, 안검하수, 뇌막염, 시력장애, 협부종창, 후각감퇴 등 의 합병증이 생길 수 있어 조기진단이 임상적으로 중요하다. ${ }^{8)}$ 비중격이 가장 호발하는 부위로 종종 비중격천공이 발생할 수 있다. 그 다음으로는 하비갑개가 호발하는 부위로 알려져 있다. 여자가 남성보다 두 배 정도 흔하며, 주로 청년기에 호발 한다. ${ }^{79)}$ 본 연구에서도 주로 젊은 여자에서 발생하였다.

진단을 위해 자세한 병력 청취가 중요하다. 증상의 강도, 양 상, 중등도 및 전신 증상의 유무를 판단해야 한다. 상기도 및 폐 등에 대한 자세한 신체검사가 필요하며 폐결핵의 과거력이
있을 때는 비결핵의 진단에 도움이 된다. 전비경 검사 상 특징 적인 육아종성 증식, 궤양, 선홍색의 결절성 비후를 보일 때 비결핵을 의심할 수 있다. 전혈구 검사, erythrocyte sedimentation rate, blood urea nitrogen, creatinine, 요 검사 등은 전 신 질환과 합병될 수 있는 육아종성 질환을 감별하는 데 도움 이 되며 매독형광항체 흡수검사법(FTA-ABS), 흥부 방사선 검사, $\mathrm{PPD}$ 를 시행한다. $\mathrm{PPD}$ 는 이전에 Ba-cillus CalmetteGuérin(BCG) 접종을 한 경우 위양성률이 높아 해석에 주의 가 필요하다. 비강 내 분비물이 있을 시에는 세균, 진균 및 항 산성 염색을 시행하며 배양 검사를 시행한다." 그러나 항산성 염색법은 빠른 결과를 얻을 수 있는 반면 $1 \mathrm{~mL}$ 당 10000 개 이상의 결핵균이 있어야 검출할 수 있으므로 특히 폐외결핵 에서는 민감도가 낮은 것으로 알려져 있다. 배양 검사는 민감 도가 염색법에 비하여 높으나 배양 기간이 6 10주 정도 소요 되어 임상적으로 이용하기에 불편한 점이 많다. 하지만 결핵의 적절한 치료를 위해 약제감수성검사 결과가 중요한데 이를 위 해서는 배양 검사가 필요하다. 이번 증례에서는 항산성 염색 법과 배양 검사를 폐결핵의 동반 여부를 감별하기 위해 객담 에서만 시행하였다. 조직 검사가 진단에 가장 중요하며 필요 시 반복적으로 검사를 시행해야 한다.

결핵은 조직학적으로 상피양의 거대세포와 건락성 괴사를 특징으로 하는 육아종성 염증을 보이며 베게너 육아종과 달 리 혈관염은 관찰되지 않는다. 하지만 전형적인 결핵 조직 소 견 없이 육아종성 염증 소견만 보인다면 감별이 어렵다. 매독, yaws, 나병, 히스토플라즈마진균증, 콕시디오이데스진균증과 같은 감염성 질환에서 비강의 육아종이 생길 수 있어 감별을 요하며 베게너 육아종, sarcoidosis 등은 전신질환과 함께 비 강의 육아종이 같이 동반될 수 있어 감별해야 한다.2, ${ }^{2,10)}$ 또한, 드물게 비인두강에 생긴 경우 본 증례들에서와 같이 결핵성 임파선 농양으로 나타날 수도 있으므로, 경부 종물과도 감별 이 필요할 수 있다.

$\mathrm{Tb}-\mathrm{PCR}$ 은 진단에 좋은 검사법으로 48시간 내에 세균 배 양 검사와 연관지어 진단할 수 있는 장점이 있으며 비교적 저 렴한 가격으로 검사할 수 있다.11) 그러나 사균에서도 양성 결과 가 나올 수 있기에 $\mathrm{Tb}-\mathrm{PCR}$ 은 진단을 확진하는 데만 이용할 수 있으며 추적 관찰에는 제한점이 있으며 민감도가 낮다. ${ }^{3)}$ 이 번 증례에서도 6예 중 1예에서만 Tb-PCR에 양성으로 나왔다. $\mathrm{Ha}$ 와 Lee $\mathrm{L}^{12}$ 는 폐외결핵 환자 15 예 중 7예에서만 $\mathrm{Tb}-\mathrm{PCR}$ 에 양성으로 검출률이 $50 \%$ 미만이나 각각 4 예와 5 예의 양성률 을 보인 항산성 염색법이나 배양 검사보다 민감도가 높다고 보고하였다. 따라서 $\mathrm{Tb}-\mathrm{PCR}$ 이 음성이라도 결핵의 가능성을 배제해서는 안 되며, 반복적인 조직 검사와 경험적인 항결핵 제 약물 치료가 필요하다. 
Quantiferon-Tb는 결핵항원에 대한 T 세포의 면역 반응을 검출하는 검사로 세균 배양 검사나 조직학적으로 진단이 힘들 때 폐외결핵을 진단하는 데 좋은 검사 방법이다. $\mathrm{PPD}$ 에 비해 $\mathrm{BCG}$ 예방접종의 영향을 적게 받는 장점이 있으나, 잠복기의 결핵 감염과 효율적으로 감별하기 힘들다. ${ }^{13)} \mathrm{Ha}$ 와 $\mathrm{Lee}^{12)}$ 는 폐 외결핵 환자 15예 중 12예인 80\%에서 Quantiferon-Tb에 양 성으로 폐외결핵의 진단에 특히 유용하다고 보고하였다.

비강 및 비인두결핵을 진단하기 위하여 모든 검사실에서 P$\mathrm{PD}$, 항산성 염색법, 배양 검사, 조직 검사, $\mathrm{Tb}-\mathrm{PCR}$, Quantife$\mathrm{ron}-\mathrm{Tb}$ 등의 여섯 가지 검사를 시행하기는 어려울 것이다. 하 지만 비강 내 분비물이 있다면 전통적인 검사인 항산성 염색 법 및 배양 검사를 시행하며, 조직 검사와 함께 민감도가 높은 $\mathrm{Tb}-\mathrm{PCR}$ 과 Quantiferon- $\mathrm{Tb}$ 를 시행하면 신속하고 정확한 결 핵 진단에 유용할 것으로 생각된다.

비강 및 비인두결핵의 치료를 위해서는 복합 항결핵제 요법 과 함께 비강 내의 비루, 가피 등을 제거해주며 환자가 자가 세 척해 주도록 교육하는 것이 중요하다. ${ }^{2)}$ 항결핵제 처방은 폐결 핵과 동일한 방법으로 약 6 개월에서 1년 여간 치료하며 저자들 이 경험한 예들에서도 6 개월에서 14 개월간 isoniazid, rifampin, ethambutol, pyrazinamide 등을 투여하여 재발 없이 완 치시킬 수 있었다.

치료 경과에 대한 평가는 배양 등 세균학적인 검사 결과보 다는 임상 증상과 비인두경 검사 및 영상 의학적 소견에 근거 하여 판단해야 하는 어려움이 있다.

결론적으로, 비루, 비폐색이 있는 환자에서 비점막의 궤양 이나 육아 병변이 있을 때는 결핵의 가능성을 염두에 두어야
한다. 또한 조기 진단을 위해 조직 검사를 시행하고, 초기에 경험적인 항결핵제 약물 치료가 필요하다.

\section{REFERENCES}

1) World Health Organization. Global tuberculosis control: a short update to the 2012 report. Geneva: World Health Organization; 2012.

2) Waldman SR, Levine HL, Sebek BA, Parker W, Tucker HM. Nasal tuberculosis: a forgotten entity. Laryngoscope 1981;91(1):11-6.

3) Al-Serhani AM. Mycobacterial infection of the head and neck: presentation and diagnosis. Laryngoscope 2001;111(11 Pt 1):2012-6.

4) Butt AA. Nasal tuberculosis in the 20th century. Am J Med Sci 1997;313(6):332-5.

5) Goguen LA, Karmody CS. Nasal tuberculosis. Otolaryngol Head Neck Surg 1995;113(1):131-5.

6) Kim YM, Kim AY, Park YH, Kim DH, Rha KS. Eight cases of nasal tuberculosis. Otolaryngol Head Neck Surg 2007;137(3):500-4.

7) Park CH, Kim HY, Rha KS, Park CI. Tuberculosis of the nasal cavity and paranasal sinuses. Korean J Otolaryngol-Head Neck Surg 2003; 46(11):979-83.

8) Park JH, Lee BJ. Four cases of sinonasal tuberculosis. Korean J Otolaryngol-Head Neck Surg 1998;41(1):126-9.

9) Choi YC, Park YS, Jeon EJ, Song SH. The disappeared disease: tuberculosis of the nasal septum. Rhinology 2000;38(2):90-2.

10) Hong YS, Choi HS, Lee SS, Lim SC. A case of primary sarcoidosis of the nasal cavity. Korean J Otorhinolaryngol-Head Neck Surg 2008;51(10):938-41.

11) Brisson-Noel A, Aznar C, Chureau C, Nguyen S, Pierre C, Bartoli $\mathrm{M}$, et al. Diagnosis of tuberculosis by DNA amplification in clinical practice evaluation. Lancet 1991;338(8763):364-6.

12) Ha GY, Lee YH. Clinical usefulness of various methods for the diagnosis of tuberculosis. Korean J Clin Pathol 2000;20(5):494-500.

13) Fan L, Chen Z, Hao XH, Hu ZY, Xiao HP. Interferon-gamma release assays for the diagnosis of extrapulmonary tuberculosis: a systematic review and meta-analysis. FEMS Immunol Med Microbiol 2012;65 (3):456-66. 